\title{
Mechanical Dissociation of Retinal Neurons with Vibration
}

\author{
Tamami Motomura Student Member (Kumamoto University) \\ Yuki Hayashida Member (Kumamoto University, yukih@cs.kumamoto-u.ac.jp) \\ Nobuki Murayama Member (Kumamoto University)
}

\begin{abstract}
Keywords : neurophysiological engineering, neuromorphic device, single neuron, nonlinear membrane conductance, cell dissociation, patch-clamp technique
\end{abstract}

The neuromorphic artificial device, like silicon retinas, has been collecting much attention in the engineering fields in the last decade. Concurrently, progress in neuroscience research has revealed the nonlinear computation in single neuron levels, suggesting that individual neurons are not merely the circuit elements but computational units. Thus, elucidating the properties of neuronal signal processing is thought to be an essential step for developing the next generation of neuromorphic devices. However, the methods previously used for dissociating the retinal tissue into single neurons have commonly entailed enzymatic digestions which might distort the membrane conductances. In the present study, we developed a new method for dissociating neurons from specific sublayers of mammalian retinas with using no proteolytic enzyme but rather combining tissue incubation in a low-Ca ${ }^{2+}$ medium and the vibro-dissociation technique developed for the slices of brains and spinal cords previously.

Figure 1 shows the protocol in the method for dissociating cells from the ganglion cell layer (see the legend for detail). When compared with the conventional enzymatic method, our method took shorter time of the procedure, and required less elaborate skill; nevertheless it yielded enough number of the neurons available for acute electrophysiological experiments. The isolated neurons were in morphologically good condition, and could be identified as ganglion cells with the size criterion. Those cells were useful for the measurements of intrinsic membrane properties under the perforated-patch whole-cell configuration. In response to depolarizing constant current injections, some of the cells could generate spikes in the sustained manner with the accommodation and some others showed transient firing or burst of spikes. Under the voltage-clamp, the cells showed the large amplitude of voltage-gated $\mathrm{Na}^{+}$current and the delayed activation of net outward currents in response to depolarization steps. Moreover, since the cells dissociated by our method were never exposed to proteolytic enzymes, they enabled us to examine the effects of enzymatic digestion on the membrane properties in those cells. Spike firing of the cells in response to a depolarizing current injection was continuously recorded before, during and after the application of an enzyme solution. And we found an evidence for possible distortion of the membrane excitability by the enzyme. These results indicate that the single retinal neurons dissociated by our new method are superior to ones dissociated by the previous enzymatic method, in terms of the native electrophysiological properties without the influence of proteolysis. We believe this is valuable for quantitative analyses on the computational properties in single neuron levels.

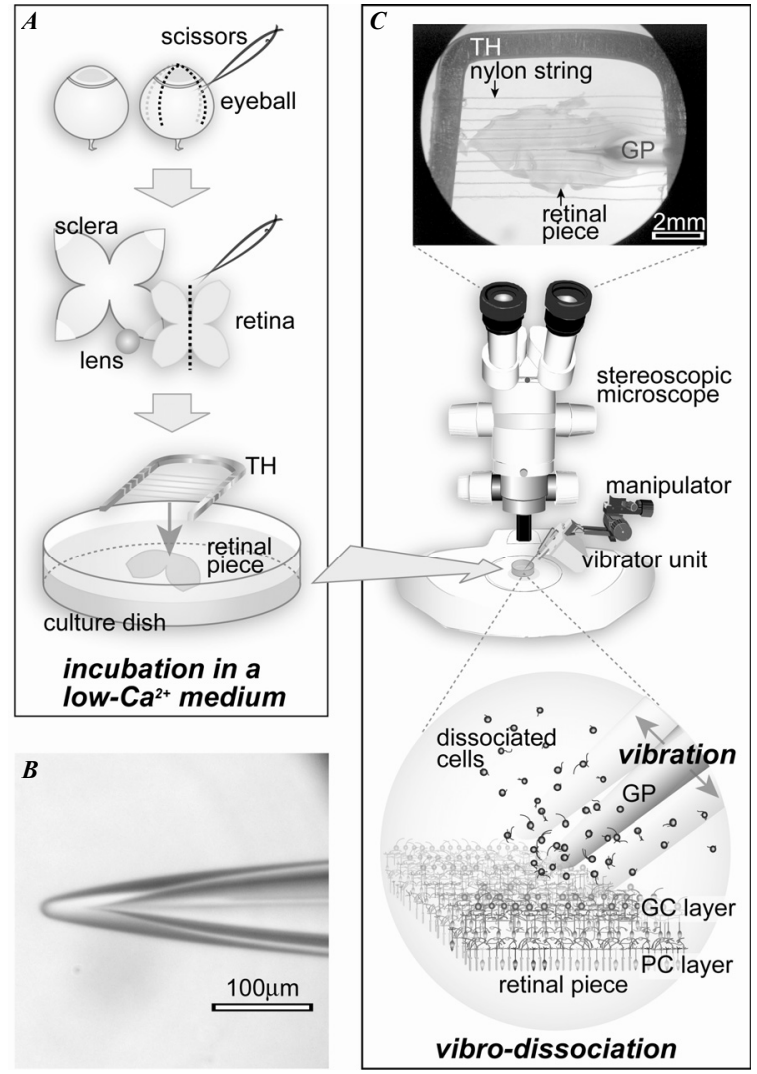

Fig. 1. Protocol in the method we developed to dissociate retinal neurons. $A$, Low- $\mathrm{Ca}^{2+}$ tissue incubation. After isolating neuronal retinas from rat eyes, the tissue was cut into 2-4 pieces, and incubated in a low- $\mathrm{Ca}^{2+}$ medium for 3-5 min. TH: tissue holder. $B$, Microphotograph of the tip of a fire-blunted glass pipette. $C$, Vibrodissociation. After the low-Ca ${ }^{2+}$ incubation in $A$, the retinal piece was placed under a microscope. High-speed horizontal vibration was applied to the retinal surface with using the glass pipette (GP) mounted on the vibrator unit. Position of the pipette tip was controlled with the manipulator. Top inset, Photograph of the view in microscope. Bottom inset, Schematic drawing of the pipette vibrating at the retinal surface, and of the cells dissociated from the ganglion cell (GP) layer. PC: photoreceptor cell 


\title{
網膜神経細胞の機械的振動単離法
}

学生員 本村 珠美* 正 員 林田 祐樹*
正 員 村山 伸樹*

\author{
Mechanical Dissociation of Retinal Neurons with Vibration \\ Tamami Motomura*, Student Member, Yuki Hayashida*, Member, Nobuki Murayama*, Member
}

The neuromorphic device, which implements the functions of biological neural circuits by means of VLSI technology, has been collecting much attention in the engineering fields in the last decade. Concurrently, progress in neuroscience research has revealed the nonlinear computation in single neuron levels, suggesting that individual neurons are not merely the circuit elements but computational units. Thus, elucidating the properties of neuronal signal processing is thought to be an essential step for developing the next generation of neuromorphic devices. In the present study, we developed a method for dissociating single neurons from specific sublayers of mammalian retinas with using no proteolytic enzymes but rather combining tissue incubation in a low-Ca ${ }^{2+}$ medium and the vibro-dissociation technique developed for the slices of brains and spinal cords previously. Our method took shorter time of the procedure, and required less elaborated skill, than the conventional enzymatic method did; nevertheless it yielded enough number of the cells available for acute electrophysiological experiments. The isolated retinal neurons were useful for measuring the nonlinear membrane conductances as well as the spike firing properties under the perforated-patch whole-cell configuration. These neurons also enabled us to examine the effects of proteolytic enzymes on the membrane excitability in those cells.

キーワード : 神経生理工学, 神経模倣型デバイス, 単一神経細胞, 非線形膜コンダクタンス, 細胞単離, パッチクランプ法

Keywords : neurophysiological engineering, neuromorphic device, single neuron, nonlinear membrane conductance, cell dissociation, patch-clamp technique

\section{1. はじめに}

近年，生体神経の機能や構造を模倣した人工デバイスが 工学の分野で注目を集めている。中でも十数年前に Mead ら により開発されたシリコン網膜は，脊椎動物網膜が持つ神 経回路構造を CMOS 回路技術によりインプリメントしよう としたものであり，それまでの汎用電子計算機を用いたシ ステムが不得手とした感覚情報の並列実時間処理に対し て, 新しい実現手法を提案するものであった ${ }^{(1)}$ 。しかし近年 の神経科学研究により, それまで単純なアナログ素子とし て近似されてきた個々の神経細胞が，生体においては一つ の演算ユニットとして機能していることが示されるように なってきた (2)。これは, 神経細胞自体が持つ信号処理特性を 定量的に明らかにすることが，次世代の生体神経模倣型デ バイスを開発する上での重要なステップであることを示唆 している。

\footnotetext{
熊本大学大学院自然科学研究科

干860-8555 熊本県熊本市黒髪 2-39-1

Graduate school of Sci. \& Tech. Kumamoto Univ.,

2-39-1 Kurokami, Kumamoto-shi, Kumamoto 860-8555
}

最近，“時空間コントラスト順応”や“運動の予測”， “地と図の運動分離” などといった高次の視覚情報処理 が，網膜の段階で既に始まっていることが分かってきた ${ }^{(3)}$ 。 特に, 回路の出力段に位置する神経節細胞において行われ る非線形演算が，それら高次機能に大きく寄与しているこ とが示唆されている(4)〜(6)。しかし，その処理を支える非線 形膜特性に関しては定量的な生理学実験データがそしく, 依然として神経節細胞の正確なバイオフィジックスモデル を構築できるまでには至っていない(7) (9)。

一般的に回路の構成ユニットが持つ特性を計測するに は，他との相互干涉を除くため，各ユニットを回路から切 り離す必要がある。従来, 神経組織より個々の神経細胞を 単離する過程では, 細胞間の結合を弱めるために蛋白質分 解酵素を用いた処理が用いられてきた ${ }^{(10)}$ 。しかしながら神 経細胞の細胞膜上に存在する伝達物質受容体やイオンチャ ネルの特性が, その酵素処理により著しく変性を受けてし まうことが報告されている $\left(\mathrm{Na}^{+} / \mathrm{K}^{+} /\right.$陽イオン $/ \mathrm{Ca}^{2+}$ チャネ ル(11) (17), ACh/NMDA 受容体 $\left.{ }^{(17)(18)}\right)$ 。したがって過去の生 理学実験で計測された神経細胞の受動的/能動的な膜特性 
は，その酵素処理の悪影響を受けている可能性がある。こ れに対し, 酵素を一切使用することなく, 主に機械的振動 処理によって組織から神経細胞を単離する “vibro-dissociation 法” が近年開発され(19)，大脳基底核，視 床下部，海馬，脊髄などのスライス試料に適用されてき た ${ }^{(20)}$ 。そこで本研究では, 網膜細胞の単離に有効な低濃度 $\mathrm{Ca}^{2+}$ 溶液インキュベーション (21) と, この機械的振動処理と を組み合わせ, 網膜組織の特定の細胞層から神経細胞を機 械的に単離する新規方法を開発した ${ }^{(22)}$ 。さらに，この方法 によって得られた単離神経細胞が，非線形膜特性の計測な どの急性の電気生理学実験に使用可能な試料であるかを, perforated-patch whole-cell（穿孔パッチホールセル）記録(23) により検証した。

\section{2. 実験方法}

〈2·1〉 細胞単離エーテル麻酔下のラット（Wistar 系，生後 7-25日）より摘出した眼球をエタノール及び生理 食塩水で濯いだのち，メンブレンフィルタ上に置き角膜側 から十字に切開した（図 $1 A$ 上段）。レンズ，内境界膜等を 取り除き, 強膜より剥離した網膜を 2 片ないし 4 片に切り 分けた (図 $1 A$ 中段)。網膜片は冷やした細胞外溶液内で一 時保存した。この溶液の組成は $(\mathrm{mM}): 140 \mathrm{NaCl}, 3.5 \mathrm{KCl}, 1$ $\mathrm{MgCl}_{2}, 2.5 \mathrm{CaCl}_{2}, 10$ D-glucose, 5 HEPES であり， $\mathrm{NaOH} に よ$ り $\mathrm{pH} 7.3$ に滴定した（浸透圧は 280-290 mOsmol $\left./ \mathrm{kg}^{(24)}\right)$ 。表 面加工の施された細胞培養典（3801，FALCON，Franklin Lakes, NJ ; 直径 $35 \mathrm{~mm}$ ) に網膜片を取り出し, 神経節細胞 層（図中 GC layer）を上にして平らに広げ，ナイロン線を張 った U 字型の試料押さえ（図中 $\mathrm{TH}$ ) で固定した。組織内の 細胞間結合を緩めるため, 網膜片を low-Ca ${ }^{2+}$ 溶液中 $(0.4 \mathrm{ml})$ にて 3-5 min のインキュベーションを行った（図 $1 A$ 下段）。 ここで用いた low-Ca ${ }^{2+}$ 溶液の組成は $(\mathrm{mM}): 140$ sucrose, 2.5 $\mathrm{KCl}, 70 \mathrm{CsOH}, 20 \mathrm{NaOH}, 1 \mathrm{NaH}_{2} \mathrm{PO}_{4}, 15 \mathrm{CaCl}_{2}, 20$ EDTA, 11 D-glucose, 15 HEPES であり, HClにより pH7.2 に滴定した(浸 透圧は 290-300 mOsmol $/ \mathrm{kg}$ )。この溶液中の推定遊離 $\mathrm{Ca}^{2+}$ 濃 度は 100-200 nM であった。インキュベーション処理を施さ なかった網膜試料においては, 後述の機械的振動処理によ つて神経細胞は殆ど単離されなかった ${ }^{(21)}$ 。

インキュベーション終了後，熱処理により細く滑らかに 加工したガラス管の先端を (図 $1 B$, 図 $1 C$ 中 $\mathrm{GP}$ ), 実体顕微 鏡下のマニピュレータ操作により網膜片の表面に僅かに接 触させ, 水平方向に振幅 0.2-0.5 mm, 周波数 10-100 Hz で振 動させた（図 $1 C$ 上中段）。ガラス管は予め電動式の振動ユ ニット (SI-10, K. T. Labs., 埼玉; 振動周波数 10-100 Hz 可変) に取り付けられた。水平振動するガラス管で網膜表面全体 を走査することにより，表層の神経節細胞層より細胞が単 離された（図 $1 C$ 下段，以下，振動処理と呼ぶ)。網膜片 1 枚当たり約 $5 \mathrm{~min}$ の振動処理を行った後, 試料押さえと残っ た網膜片を取り除き，培養典内を細胞外溶液 $3 \mathrm{ml}$ で満たし た。単離細胞を培養血底面に定着させるため, 培養血を除 振台上で $15 \mathrm{~min}$ 程度静置した。培養血内の溶液を培養液 (上

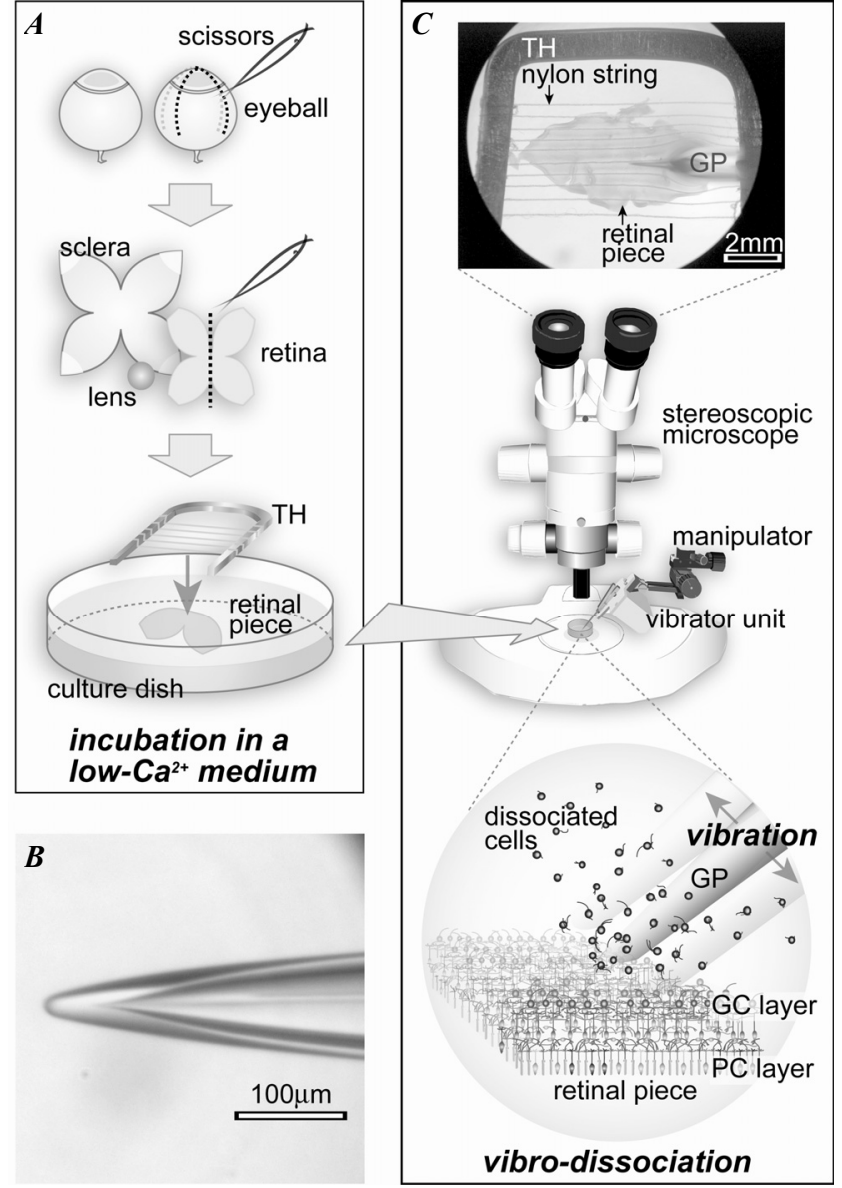

図 1 開発した網膜神経細胞単離法の操作手順

Fig. 1. Protocol in the method we developed to dissociate retinal neurons. TH: tissue holder, GP: glass pipette, GC: ganglion cell, PC: photoreceptor cell.

記の細胞外溶液にウシ血清アルブミン $1 \mathrm{mg} / \mathrm{ml}$ を添加した もの）に新しく交換し，培養皿を除振台上でさらに $1.5 \mathrm{hr}$ 以上静置して, 単離操作によるダメージから細胞が十分回 復するのを待った。但し, 後述の膜電位固定実験における space-clamp の誤差要因を軽減するため ${ }^{(25)}$, 培養血は室温 $\left(20-25{ }^{\circ} \mathrm{C}\right)$ に保ち, 新たな神経突起が再生/伸張するのをで きる限り抑えた ${ }^{(26)}$ (図 $5 A$ )。また単離された段階で比較的 長い神経突起を保持していた細胞は, 膜電流固定実験に用 いた（図 $4 A$ )。

今回開発した上述の単離方法に対し, 従来の酵素を用いた 方法でもラット網膜からの細胞単離を行った $(n=3)$ 。単離の プロトコルは過去の報告に倣った(27)(28)。先ず剥離した網膜 を酵素溶液中 $\left(29^{\circ} \mathrm{C}\right)$ にて $20 \mathrm{~min}$ インキュベートした。酵 素溶液には， $0.25 \mathrm{mg} / \mathrm{ml}$ papain (\#5125, Calbiochem), $2.5 \mathrm{mM}$ ${ }_{\mathrm{L}}$-cystein を上述の細胞外溶液に添加して用いた。酵素処理 後, 網膜を冷やした細胞外溶液にて, 溶液を新しいものに 交換しながら 6 回濯いだ (約 30-40 min)。なお始めの 2 回は ウシ血清アルブミン $1 \mathrm{mg} / \mathrm{ml}$ を添加したものを用いた。そ の後, ガラスピペットによる機械的処理（trituration と呼ば れる）を，4-5 回の段階に分け熟練者の手により行った（約 
30-50 min)。trituration 後の細胞懸濁液を培養血に滴下し，単 離細胞が底面に定着するのを待って培養液を満たした。

$\langle 2 \cdot 2\rangle$ 電気生理学実験上述の方法で単離した神経 細胞を用い, 膜電位固定下の非線形膜コンダクタンスの測 定，および電流注入に対する活動電位（スパイク）発火応 答の計測を行った。計測中, 培養血内の溶液を新鮮な細胞 外溶液により絶えず灌流した。Y 字型灌流チューブの先端 口（内径約 $250 \mu \mathrm{m} ） を$ 位置に置き, 流量約 $0.4 \mathrm{ml} / \mathrm{min}$ で溶液の供給を行った。培養 皿の縁から溶液の排出を行い, 培養血内の液量を約 $2 \mathrm{ml}$ の 一定に保った。試薬投与も $\mathrm{Y}$ 字型灌流チューブを用いて行 った。

近年, 網膜神経節細胞のスパイク発火及び膜コンダクタ ンスが $\mathrm{Zn}^{2+}$ や cAMP などの細胞内生理活性物質により修飾 され, 従来から広く用いられてきた ruptured-patch whole-cell 記録では，それらの特性が計測の時間経過と共に著しく変 化してしまう事が示されている(29) (31)。そこで本研究におい ても, 細胞内環境をできる限り保持するため, 全ての計測 を穿孔パッチホールセル記録にて行った。計測に用いるパ ッチ電極は, 垂直式二段引きプラー (PC-10, NARISHIGE，東 京）を用い, 洗浄・滅菌したホウケイ酸塩ガラス管（外径 約 $1.5 \mathrm{~mm}$, 内径約 $0.9 \mathrm{~mm}$, 芯入) より, 電極抵抗 4-8 $\mathrm{M} \Omega$ となるよう作製した。電極内液の組成は $(\mathrm{mM}): 110$ K-D-gluconic acid, $15 \mathrm{KCl}, 15 \mathrm{NaOH}, 2.6 \mathrm{MgCl}_{2}, 0.34 \mathrm{CaCl}_{2}, 1$ EGTA, 10 HEPES であり, methanesulfonic acid により pH7.2 に滴定した（浸透圧は $260 \mathrm{mOsmol} / \mathrm{kg}$ )。実験直前に, パッ チ膜の穿孔剂として Amphotericin $\mathrm{B}^{(32)}$ 電極内液に添加し (260 $\mu \mathrm{g} / \mathrm{ml}$ Amphotericin B, 200-400 $\mu \mathrm{g} / \mathrm{ml}$ Pluronic F-127)， パ ッチ電極に後方充填した。なお電極先端には穿孔剤未添加 の内液を充填した。細胞外溶液を寒天橋 $(10-20 \mathrm{mg} / \mathrm{ml}$ Agar, $150 \mathrm{mM} \mathrm{NaCl})$ を介し接地した（信号アース）。電極先端と 細胞膜とのギガオームシール形成後, 穿孔剂の働きによっ てパッチ膜部の抵抗が 10-100 M $\Omega$ まで下がり安定するのを 確認して計測を開始した。信号増幅にはパッチクランプア ンプ (EPC-10, HEKA, Lambrecht) を用いた。必要に応じ, 電 極抵抗およびパッチ膜抵抗（以下，両抵抗の直列合成とし てシリーズ抵抗と呼ぶ), 電極容量, 膜容量をアンプの内部 回路により補償した。パッチクランプアンプの出力信号は, アンプ内蔵の低域通過アナログフィルタ（初段：3-pole Bessel, 10-30 kHz cut-off; 後段 : 4-pole Bessel, 2-5 kHz cut-off) 及び A/D 変換 (5-20 kHz sampling) を介しパソコン に取り込んだ。データ取得と刺激波形生成には専用ソフト (pulse ver8.65-8.79, HEKA, Lambrecht) を用いた。計測は単離 操作終了後 $24 \mathrm{hr}$ 以内に室温にて行った。その他詳細は過去 の論文を参照 ${ }^{(21)(31)}$ 。

\section{3. 実験結果}

〈3.1〉 単離神経細胞今回開発した新規方法により ラット網膜の神経節細胞層から単離した細胞を図 2 に示す。 単離された細胞の多くはほぼ細胞体部のみであったが（図
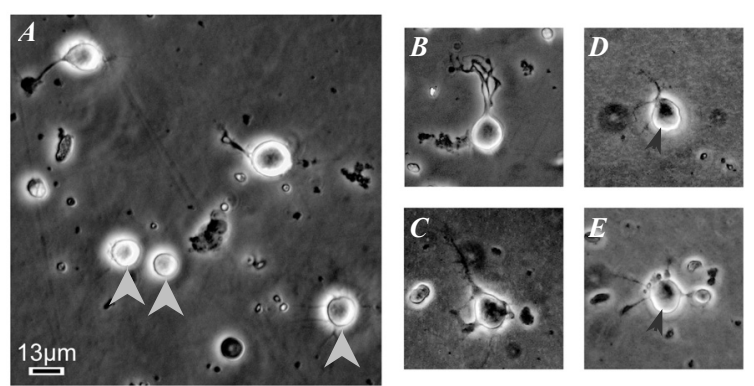

図 2 網膜神経節細胞層より単離した細胞の顕微鏡写真

Fig. 2. Micrographs of cells dissociated from retinal ganglion cell layer.

$2 A$ 矢頭, 図 $5 A$ ), 中には樹状突起と思われる神経突起を保 持した状態で細胞が単離される例もあった（図 $2 B-C$, 図 $4 A)$ 。また今回は室温下であったため, 樹状突起のような比 較的太い神経突起が新たに再生/成長することは殆ど無か ったが，成長円錐の活動は確認された。位相差顕微鏡によ る観察から, 細胞体の厚みと適度な透明度, 膜表面の平滑 さを認め, また単離後 $48 \mathrm{hr}$ 経過しても形態学的変性が認め られないことから, 新規単離法で得られた単一細胞試料が, 少なくとも形態学的には健全な状態であると言えた。

ラット網膜の神経節細胞層には神経節細胞以外に異所性 アマクリン細胞が存在する ${ }^{(33)}$ 。但し過去のラット網膜単離 細胞に関する形態学的研究によれば, 細胞体直径が $12 \mu \mathrm{m}$ よりも大きい細胞は神経節細胞として同定できる事が示さ れている ${ }^{(34)}$ 。また別の研究では, 神経節細胞の軸索切断後 に核小体肥大が起こることが分かっている ${ }^{(35)}$ 。本研究にお いても, 細胞体直径が $13 \mu \mathrm{m}$ 以上の細胞で僅かながら核小 体肥大が見られ (図 $2 D-E$ 矢印), 神経節細胞の同定基準に 関する過去の結果を支持するものであった。また $13 \mu \mathrm{m}$ 以 上の単離細胞に対して電流注入を行ったところ, 全ての細 胞でスパイク発火が惹起され, 神経節細胞としての電気生 理学的な必要条件を満たしていた。

$\langle 3 \cdot 2\rangle$ 単離細胞数単離される細胞の数と振動処理 $(\langle 2 \cdot 2\rangle$ 節参照 $)$ に用いる振動周波数との関係を調べた。そ の結果を図 3 に示す。なおここでは, 細胞単離後 2-3 hr 経過 した後, 形態学的に健全と判断した細胞体直径 $13 \mu \mathrm{m}$ 以上 の細胞のみを計数対象とした。このとき位相差顕微鏡によ る観察では，ステージ上に置いた培養皿内の中央直径約 20 $\mathrm{mm}$ 以内で正常な位相コントラストの像が得られた。従って この範囲内にある細胞を観察及び計数の対象とし, それ以 外の培養血内周辺にある細胞の計数は行わなかった。振動 周波数には, $10,50,100 \mathrm{~Hz}$ の 3 つを用い, 各周波数につき 二等分した網膜片 13 枚を用いた。その結果, 網膜片 1 枚当 たりの単離細胞数の平均土標準誤差は, $10 \mathrm{~Hz}$ で $7.3 \pm 1.2$,

$50 \mathrm{~Hz}$ で $11.6 \pm 1.4,100 \mathrm{~Hz}$ で $13.2 \pm 1.4$ となった。一元配置 分散分析による検定の結果, 3 群間に統計的有意差が認めら れ $(F=5.06, P=0.012)$, また Holm-Sidak 法による多重比較の 結果, $10 \mathrm{~Hz}$ と $100 \mathrm{~Hz}$ との間に統計的有意差 $(t=3.07$, $P=0.004)$ が認められた。そこで今回は主に $100 \mathrm{~Hz}$ の振動周 


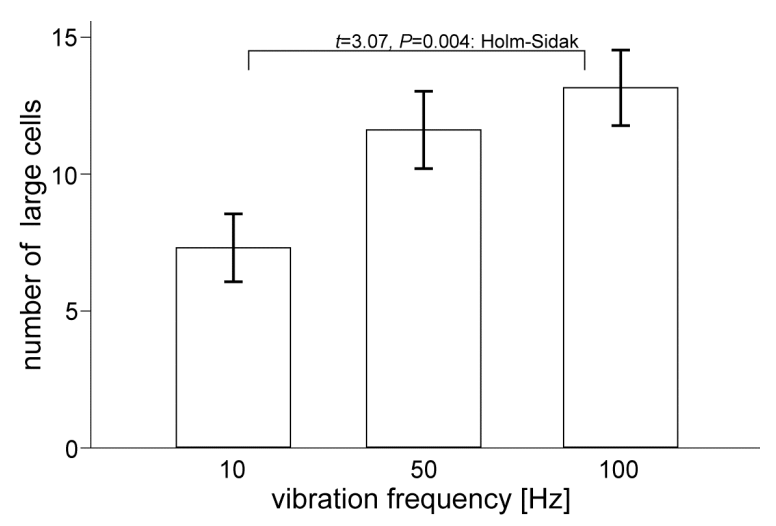

図 3 振動周波数と単離細胞数との関係

Fig. 3. Number of large cells dissociated with different vibration frequencies.

波数を神経節細胞層からの細胞単離に用いた。

培養皿内周辺部では細胞の形態学的観察は困難であった が，単離された細胞は培養皿全体におよそ均一に分布して いた。従って, $100 \mathrm{~Hz}$ を用いた場合に両眼網膜から単離さ れた細胞（但し細胞体直径 $13 \mu \mathrm{m}$ 以上）の総数は，培養典 底面の面積比率から平均 160 程度と推定された。今回, 振 動処理の時間を約 $5 \mathrm{~min}$ としたが $(\langle 2 \cdot 1\rangle$ 節参照 $)$, さらに 長時間の処理を行うことで単離される細胞数は増加した。 しかし通常の急性実験は単離後 $24 \mathrm{hr}$ 以内に行うことが多い ため ${ }^{(36)}$ ，上記の細胞数は単離細胞の電気生理学的特性の計 測を行う上で十分な数であると判断した。

$\langle 3 \cdot 3\rangle$ 従来法との比較 今回, 網膜組織の持つ層構 造を利用することにより，神経節細胞層から選択的に細胞 を単離した (図 $2 A$ )。形態学的観察のみからアマクリン細胞 之細胞体直径の比較的小さい神経節細胞とを区別する事は できなかったが ${ }^{(34)}$ ，少なくとも双極細胞や水平細胞と思わ れる細胞は殆ど単離されなかった。同様の手順により視細 胞側に対して振動処理を適用した場合には，単離された細 胞は 9 割以上が桿体視細胞（外節部と内節部が一体のもの, もしくは分離したもの) であった。これに対し酵素を用い た方法により細胞単離を行った場合には, 細胞体直径 $13 \mu \mathrm{m}$ 以上の細胞の数は他の細胞に比べて数\%に満たず，過去の 報告と同様であった ${ }^{(34)}$ (図無し)。

新規方法においては, 左右両方の眼球摘出から単離操作 終了までに要する時間は 40-50 min であった。これに対し, 従来の酵素処理を用いた方法では 2 倍以上の $1.5-2 \mathrm{hr}$ を要し た。このとき, 酵素溶液中での網膜片のインキュベーショ ン時間は $20 \mathrm{~min}$ としたが, 過去の報告では $30 \mathrm{~min}$ 以上のイ ンキュベーション時間を設けることもあり，この場合単離 操作時間はさらに長くなる(28)(34)。

今回の方法では, 機械的振動処理の振動は電動式で与え, 操作も実体顕微鏡観察による直視下で行うため比較的容易 に細胞単離が実行できる（図 $1 C$ )。未経験者（3 名）であっ ても, 眼球摘出以降の操作について 10 回以下の訓練により 確実に細胞を単離できるようになった。これに対し，従来
法で用いられる機械的処理 (trituration) は実験者の手技に 依存し, 毎回安定した数や状態の細胞試料を得るには熟練 を要する。今回も初心者（1 名）では単離細胞の数は非常に 少なく, 細胞の形態学的状態も良好でなかった（図無し）。

$\langle 3 \cdot 4\rangle$ 電気生理学的特性の計測単離した網膜神経 細胞が急性の電気生理学的計測に使用可能か検証する為, 穿孔パッチホールセル記録法による電流注入及び膜電位固 定の実験を行った。計測には直径 $13 \mu \mathrm{m}$ 以上の細胞体を持 つ細胞を用いた。

図 4 に電流注入実験の記録例を示寸。対象細胞の細胞体 に対し(図 4A), パッチ電極よりステップ状電流パルスを細 胞内注入し，その時の膜電位応答を記録した (図 $4 B$ )。電流 パルスは振幅を-20 pA から+60 pA（10 pA 刻み）とし，持 続時間 $500 \mathrm{msec}$ で与えた (図中最下段)。各パルス間のイン ターバルは $10 \mathrm{sec}$ とした ${ }^{(31)}$ 。この細胞における入力膜容量 は約 $5.5 \mathrm{pF}$, 静止膜電位は約 $-69 \mathrm{mV}$ であった。過分極性電 流注入に対しては，ほぼ線形的な膜電位変化が見られ（図 中下から 2 段目), 膜電位約 $-60 \mathrm{mV}$ から $-95 \mathrm{mV}$ の範囲にお いて過分極活性型陽イオン電流や内向き整流性 $\mathrm{K}^{+}$電流の 活性化はこの細胞では確認されなかった。注入電流と膜電 位変化の振幅から求めた静止電位近傍の入力抵抗は約 $1.2 \mathrm{G} \Omega$ であった。脱分極性電流注入に対しては，注入の時間経過 に伴って順応的にスパイク間隔が延長する持続性スパイク 発火が見られた (例; 図中下から 3 段目)。電流振幅を増加 させると, 最初のスパイク発火までの潜時及びスパイク間 隔は短くなった (図中上 5 段)。同様の電流注入実験を行っ た 50 例の細胞において, 脱分極性電流注入に対して単発の みのスパイク発火を示寸もの，一過性スパイク発火を示す もの, バースト状スパイク発火を示寸ものなど様々なもの が観測された ${ }^{(28)}$ 。図 4 の細胞と同様に持続性のスパイク発 火パターンを示寸 5 細胞について, 注入電流振幅とスパイ ク発火率との関係を調べた。電流振幅は $+5 \mathrm{pA}$ から+65 pA

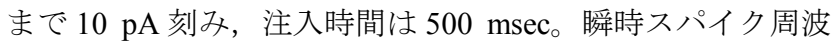
数（ここではスパイク発火 1 発目から 2 発目までのスパイ ク間隔の逆数, 図中白丸) 及び，平均スパイク周波数（ス パイク発火の総数を電流注入の持続時間で割った值，図中 灰丸）について，平均及び標準誤差 $(n=5)$ を図 $4 C$ に示す。 電流振幅の増加に伴いスパイク発火率が上昇し, また瞬時 周波数と平均周波数の差も大きくなるのが分かる。振幅 +10 $\mathrm{pA}$ 以上において平均周波数の傾きは 0.3-0.8 Hz/pA であっ た。

図 5 に膜電位固定実験の記録例を示寸. 対象細胞（図 $5 A$ ) の細胞体上のパッチ電極を介し, ステップ状に膜電位変化 を与えた時の膜電流応答を記録した (図 $5 B$ )。電圧ステップ は, 保持電位を $-70 \mathrm{mV}$ とし, $-60 \mathrm{mV}$ から+60 mV $(5 \mathrm{mV}$ 刻 み）の各電位レベルへ持続時間 $50 \mathrm{msec}$ で与えた（図では ステップの onset から $10 \mathrm{msec}$ 分を抜粋)。各電圧ステップ間

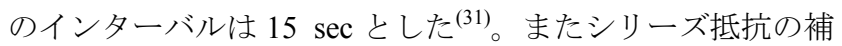
償は, 補償率 $90 \%$ (非補償分約 $2 \mathrm{M} \Omega$ ), 補償帰還ループの 時定数 $2 \mu \mathrm{sec}$ で行った。この細胞の膜容量は約 $5.7 \mathrm{pF}$, 静止 

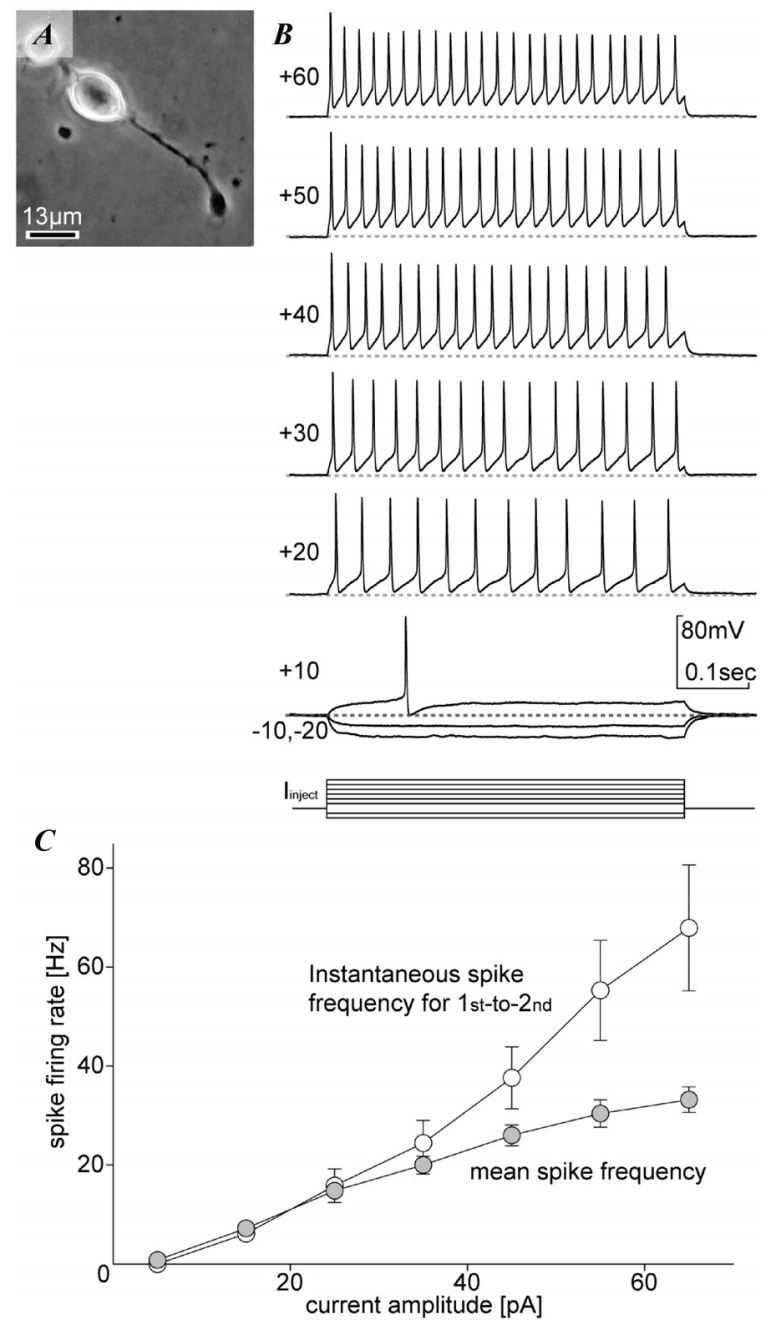

図 4 穿孔パッチホールセル記録法による電流注入に 対するスパイク発火応答の計測

Fig. 4. Recoding of spike firing in response to current injections under perforated-patch whole-cell configuration.

膜電位は約-70 mV, 静止膜電位近傍の入力抵抗は約 $2.8 \mathrm{G} \Omega$ であった。脱分極ステップに対して，保持電位付近でほぼ 受動的な電流変化が見られ, 約 $-45 \mathrm{mV}$ 以上で比較的振幅の 大きい一過性の内向き電流が活性化された。別の細胞にお いて, tetrodotoxin $(1 \mu \mathrm{M})$ 投与によりほぼ完全に電流が阻害 されたことから，この内向き電流が TTX 感受性の電位駆動 型 $\mathrm{Na}^{+}$電流であることを確認した。 $-30 \mathrm{mV}$ 以上では内向き 電流に引き続き持続性の外向き電流が活性化された。この 外向き電流は脱分極後 $50 \mathrm{msec}$ においても不活性化を示さ なかった。これら膜電流の電圧-電流 $(\mathrm{I}-\mathrm{V})$ 特性を図 $5 C$ に 示す。速い活性化時定数と不活性化を示す $\mathrm{Na}^{+}$電流につい ては，そのピーク振幅（図中白丸），比較的遅い活性化を示 す外向き電流については電圧ステップの onset 後 $10 \mathrm{msec} の$ 時点での振幅（図中灰丸）をプロットした。リーク電流成 分 (図中破線) を考慮すると, $\mathrm{Na}^{+}$電流の反転電位は $+53 \mathrm{mV}$ 付近であり, 今回の計測条件から算出された $\mathrm{Na}^{+}$の平衡電 位約 $+57 \mathrm{mV}$ にほぼ合致していた。外向き電流の I-V 特性に
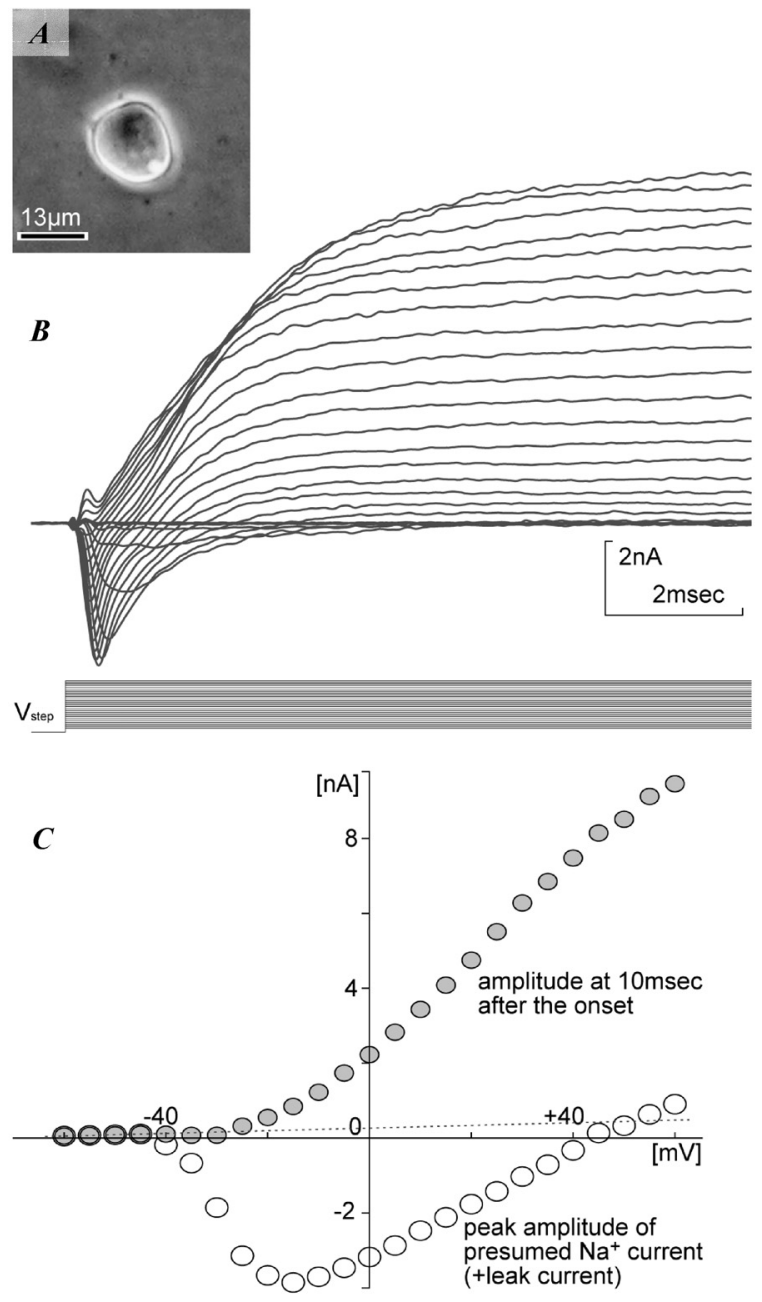

図 5 穿孔パッチホールセル記録法による電位固定下の 非線形膜コンダクタンスの計測

Fig. 5. Recoding of nonlinear membrane conductance under voltage-clamp in perforated-patch whole-cell mode.

ついては, $\mathrm{Na}^{+}, \mathrm{Ca}^{2+}$ による内向き電流, 及び $\mathrm{K}^{+}, \mathrm{Cl}^{-}$による 外向き電流を複合したコンダクタンスの特性を反映してい ると考えられる ${ }^{(37)}$ 。

\section{〈3.5〉電気生理学的特性に対する酵素処理の影響}

上述のように, 酵素処理を受けていない哺乳類網膜の単 離細胞において, 電気生理学的特性の計測が可能となった。 計測された特性は, 単離神経節細胞に関する過去の報告と 定性的には一致するように思われた(27)(28)。過去, 単離した 神経節細胞の膜興奮性には様々なタイプが存在することが 報告されている(28)。しかしそれらが，網膜内に存在する 10 種類以上の形態学的サブタイプ(38)(39)を反映した細胞本来の 特性の違いか，あるいは，酵素処理により細胞膜上のイオ ンチャネルが受けた影響の違いによるものか不明であるた め, 今回の計測結果との対応付けと定量的比較は難しい。 そこで, 従来単離法で用いられてきた酵素処理の前後で細 胞の膜興奮性を比較し, 網膜神経節細胞の電気生理学的特 性が酵素により変性し得るか否かを実験的に検証した。

酵素の影響をより直接的に調べる為, 細胞を穿孔パッチ 

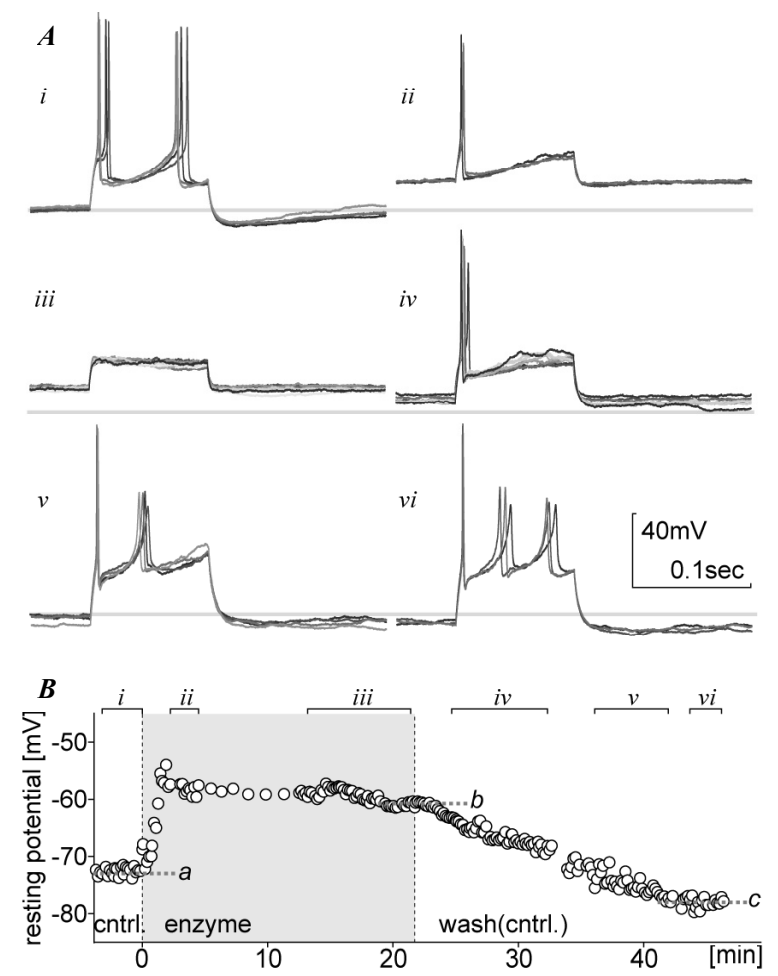

図 6 膜興奮性および静止膜電位に対する酵素溶液の影響： 穿孔パッチホールセル記録法による連続計測。 $A$ の $i$ から $v i$ のトレースは, $B$ に示寸時間帯で記録した膜電位応答 波形を3-8つ重福きしたもの。

Fig. 6. Effects of the enzyme solution on membrane excitability and resting membrane potential: Continuous recording under perforated-patch whole-cell configuration. Traces shown in $i$ to $v i$ of $A$ are superimpositions of membrane voltage responses (3-8 traces) recorded during the periods indicated in $B$.

ホールセルの状態におき，電流注入に対する膜電位応答を 計測しながら，酵素溶液を細胞外灌流した ${ }^{(16)(17)}$ 。このとき 酵素の投与時間は，従来単離法での酵素処理時間と同程度 （約 $20 \mathrm{~min} ）$ とし, 酵素溶液の組成も同じものを用いた（〈2・ 2〉節参照)。図 6 にその記録例を示す。図 4 の実験同様, パッチ電極よりステップ状電流パルスを細胞内注入し，そ の時の膜電位応答を記録した（図 $6 A$ )。電流パルスは，振幅

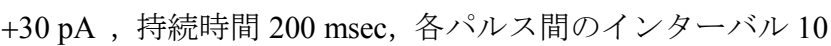
$\mathrm{sec}$ 以上で与えた。この細胞の膜容量は約 $12.7 \mathrm{pF}$ であった。 コントロール条件 $(B$, cntrl. ) における静止膜電位は約-73 $\mathrm{mV}(B, \mathrm{a})$, 静止膜電位近傍の入力抵抗は約 $1.4 \mathrm{G} \Omega$, 上記 の電流注入に対するスパイク発火の瞬時周波数は約 $8 \mathrm{~Hz}$ で あった $(A, i)$ 。酵素溶液の灌流を開始するとともに $(B$, enzyme), 静止膜電位は数分以内に脱分極し，スパイク発火 の抑制，スパイク振幅の減少が引き起こされた $(A, \quad i i)$ 。 酵素投与 $20 \mathrm{~min}$ 後で静止膜電位は約 $-59 \mathrm{mV}$ のプラトーに 達し $(B, \mathrm{~b})$, スパイク発火は完全に消失した $(A, i i i)$ 。再 び通常の細胞外液を灌流し酵素を洗い流すと $(B$, wash $)$, 静止膜電位は徐々に再分極し，電流注入に対して再びスパ
イク発火が誘発されるようになった $(A, i v-v)$ 。酵素の洗い 流し $20 \mathrm{~min}$ 後で静止膜電位約-78 mV に至り $(B, \mathrm{c})$, スパ イク発火の瞬時周波数は約 $14 \mathrm{~Hz}$ で一定となった $(A, v i)$ 。 他の細胞において同様の実験を試みたが，酵素投与により 膜電位の計測が不安定になる傾向があった。今回，図 6 と 同程度に安定した記録を別の 2 例の細胞において得ること ができた。コントロール条件下, 酵素投与約 $20 \mathrm{~min}$ 後, 酵 素の洗い流し 10-30 min 後における静止膜電位 (平均土標準 誤差, $n=3)$ は各々, $-71 \pm 0.7 \mathrm{mV},-56 \pm 5.7 \mathrm{mV},-74 \pm 2.6 \mathrm{mV}$ であり, 酵素処理の前後で顕著な変化はなかった。また 3 細胞において, 酵素処理前の瞬時スパイク周波数は, $7.7 \mathrm{~Hz}$ (上記), $11.9 \mathrm{~Hz}, 73.8 \mathrm{~Hz}$ であり, 各々に対応する酵素処理 後の瞬時スパイク周波数は, $14.1 \mathrm{~Hz}$ (上記), $27.5 \mathrm{~Hz}, 90.8$ $\mathrm{Hz}$ であった（值は全て 3-8 試行の平均值)。従って酵素処理 による瞬時スパイク周波数の上昇率は $179 \pm 31 \%$ (平均土標 準誤差, $n=3)$ であった。以上の結果は, 従来の単離法によ り得られた網膜細胞試料の電気生理学的特性が, 酵素処理 により変性を受けていた可能性の高いことを示唆してい る。

\section{4. まとめ}

本研究において, 低濃度 $\mathrm{Ca}^{2+}$ 溶液インキュベーション及 び機械的振動処理を組み合わせることにより, 酵素を一切 用いず哺乳類網膜組織の特定の細胞層より神経細胞を単離 する新規方法を開発した。従来法に比べ熟練を要せず, か つ短時間で確実に細胞試料を得ることができ，また単離し た神経細胞が急性の電気生理学実験に使用可能であること が示されたことから，新規単離法の有用性が実証された。 さらに今回, 従来の単離法で通常用いられる蛋白質分解酵 素を用いた処理が，網膜細胞の膜興奮性を変性させ得るこ とが示された。従って新規単離法で得られた単一細胞試料 は, 酵素による変性を受けていない膜特性を保持している という点において, 従来法より優れていると考えられる。 また同時に今回の細胞試料が，イオンチャネル等の膜蛋白 質に対する酵素の影響を調べるうえでも有用であると言え る。今後実験例数を増やし, 酵素の影響に関するより定量 的な検討と, それらを踏まえた上での過去のデータとの比 較が望まれる。今回は主に神経節細胞層からの細胞単離を 行ったが, アマクリン細胞, 双極細胞, 水平細胞が存在す る内顆粒層や, 視細胞内接のある外顆粒層からも, 低濃度 $\mathrm{Ca}^{2+}$ と振動処理の組み合わせにより細胞単離が可能だと考 えられる。その際, 振動処理に用いる振動周波数について, 細胞の種類に応じた最適周波数の検討が必要であろう。今 回は装置の都合上使用できなかった $100 \mathrm{~Hz}$ 以上の周波数に ついては, 神経節細胞層からの細胞単離に関しても再度最 適条件の絞り込みが望まれる。

これまで, vibrodissociation 法を用いて脳や脊骾のスライ ス試料から単離された神経細胞の細胞膜上には, シナプス 前細胞のシナプス終末部のみが機能的シナプス結合(神経伝 達物質放出機構)を保持した状態で残存していることが示さ 


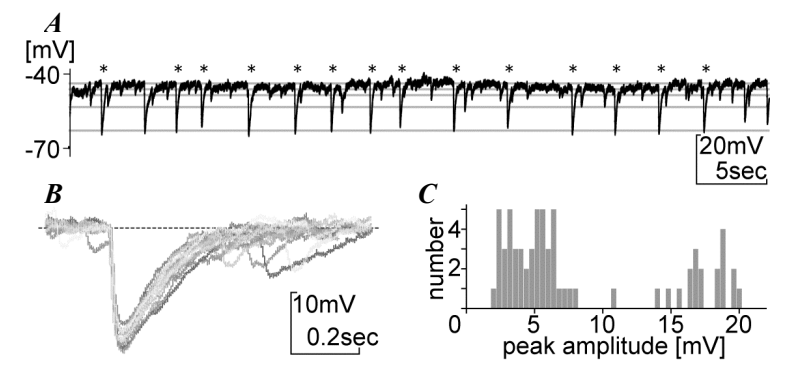

図 7 膜電流固定下で観測された IPSP 様の自発的膜電位 変化。 $A, 50 \mathrm{sec}$ の連続記録波形。 $B, A$ の*゙示した 波形を重辇きしたもの。C, $A$ で観測された 過分極のピーク振幅のヒストグラム。

Fig. 7. Spontaneous IPSP-like voltage transients recorded under current-clamp. $A$, Continuous trace of membrane voltage recorded for $50 \mathrm{sec} B$, Superimposition of the traces taken from ones indicated by asterisks in $A$. $C$, Histogram of the peak amplitude of the hyperpolarizations observed in $A$.

れている ${ }^{(14)}$ 。今回我々が計測を行った細胞においても, 約 10-20\%の割合で，抑制性後シナプス電位 (IPSP) の性質に 類似した，自発的膜電位変化が観測された。図 $7 A$ は，持続 的な電流注入により平均の膜電位レベルを約 $-40 \mathrm{mV}$ に脱分 極したときに観測された自発的膜電位変化の記録例であ る。時間波形の互いに酷似した一過性の過分極が見られ $(B)$, ピーク振幅も離散的な值を取る傾向にあった $(C)$ 。こ のような自発的な一過性膜電位変化が急性単離の網膜細胞 において観測された例は過去の報告には見当たらない。こ れが自発 IPSP を捉えたものか否か, 今後薬理学的及び形態 学的に詳細な検討が必要である。

今回開発した新規細胞単離法と穿孔パッチ記録法とを組 み合わせることにより, 細胞本来が持つ電気生理学的特性 をより正確且つ定量的に計測することが可能となった。こ の事は, 今後, 網膜神経細胞が持つ非線形信号処理のメカ ニズムをモデル化/ハードウェア化していく上で極めて重要 であると考える。

\section{謝 辞}

本研究に対して非常に有益な御教示を下さり, さらに実 験装置を快くお貸し頂きました熊本保険科学大学の赤池紀 扶教授に深謝いたします。

本研究の一部は文部科学省科学研究費補助金若手研究(B)

（課題番号：17700398，林田）の助成を受けて行った。

(平成 19 年 1 月 25 日受付, 平成 19 年 5 月 15 日再受付)

\section{文献}

(1) C. Mead and M. Mahowald : "A Silicon model of early visual processing", Neural Networks, Vol.1, No.1, pp.91-97 (1988)

(2) C. Koch and I. Segev : "The role of single neurons in information processing", Nature Neuroscience, Vol.3, suppl. 1, pp.1171-1177 (2000)

(3) S. A. Baccus : "Timing and computation in Inner retinal circuitry", Annual Review of Physiology, Vol.69, pp.271-290 (2007)

(4) K. J. Kim and F. Rieke : "Temporal contrast adaptation in the input and output signals of salamander retinal ganglion cells", Journal of Neuroscience, Vol.21, No.1, pp.287-299 (2001)

(5) M. J. 2nd Berry, I. H. Brivanlou, T. A. Jordan, and M. Meister : "Anticipation of moving stimuli by the retina", Nature, Vol.398, No.6725, pp.334-338 (1999)

(6) B. P. Olveczky, S. A. Baccus, and M. Meister : "Segregation of object and background motion in the retina", Nature, Vol.423, No.6938, pp.401-408 (2003)

( 7 ) M. C. van Rossum, B. J. O'Brien, and R. G. Smith : "Effects of noise on the spike timing precision of retinal ganglion cells", Journal of Neurophysiology, Vol.89, No.5, pp.2406-2419 (2003)

(8) K. J. Kim and F. Rieke : "Slow $\mathrm{Na}^{+}$inactivation and variance adaptation in salamander retinal ganglion cells", Journal of Neuroscience, Vol.23, No.4, pp.1506-1516 (2003)

(9) Y. Hayashida and A. T. Ishida : "Dopaminergic modulation of spikegeneration mechanism in retinal ganglion cells", Society for Neuroscience Abstract, 264.17 (2003)

(10) A. R. Kay and R. K. S. Wong : "Isolation of neurons suitable for patch-clamping from adult mammalian central nervous systems", Journal of Neuroscience Methods, Vol.16, No.3, pp.227-238 (1986)

(11) K. S. Lee, N. Akaike, and A. M. Brown : "Trypsin inhibits the action of tetrodotoxin on neurons", Nature, Vol.265, No.5596, pp.751-753 (1977)

(12) S. Hestrin and J. I. Korenbrot : "Voltage-activated potassium channels in the plasma membrane of rod outer segments: a possible effect of enzymatic cell dissociation", Journal of Neuroscience, Vol.7, No.10, pp.3072-3080 (1987)

(13) T. Budde, J. A. White, and A. R. Kay : "Hyperpolarization-activated $\mathrm{Na}^{+}-\mathrm{K}^{+}$current $\left(I_{\mathrm{h}}\right)$ in neocortical neurons is blocked by external proteolysis and internal TEA" Journal of Neurophysiology, Vol.72, No.6, pp.2737-2742 (1994)

(14) J. Shen, S. Watanabe, and A. Kaneko : "Cell dissociation with papain reduces the density of cGMP-activated channels of the retinal rod" Japanese Journal of Physiology, Vol.45, No.1, pp.151-164 (1995)

(15) P. M. Hermann, K. Lukowiak, W. C. Wildering, and A. G. Bulloch : "Pronase acutely modifies high voltage-activated calcium currents and cell properties of Lymnaea neurons", European Journal of Neuroscience, Vol.9, No.12, pp.2624-2633 (1997)

(16) C. E. Armstrong and W. M. Roberts : "Electrical properties of frog saccular hair cells: distortion by enzymatic dissociation", Journal of Neuroscience, Vol.18, No.8, pp.2962-2973 (1998)

(17) J. C. Holt, M. Lioudyno, G. Athas, M. M. Garcia, P. Perin, and P. S. Guth : "The effect of proteolytic enzymes on the $\alpha 9$-nicotinic receptor-mediated response in isolated frog vestibular hair cells", Hearing Research, Vol.152, No.1-2, pp.25-42 (2001)

(18) N. Akaike, M. Kaneda, N. Hori, and O. A. Krishtal : "Blockade of $\mathrm{N}$-methyl-D-aspartate response in enzyme-treated rat hippocampal neurons", Neuroscience Letter, Vol.87, No.1-2, pp.75-79 (1988)

(19) V. S. Vorobjev : "Vibrodissociation of sliced mammalian nervous tissue", Journal of Neuroscience Methods, Vol.38, No.2-3, pp.145-150 (1991)

(20) N. Akaike and A. J. Moorhouse : "Techniques: Applications of the nerve-bouton preparation in neuropharmacology", Trends in Pharmacological Sciences, Vol.24, No.1, pp.44-47 (2003)

(21) Y. Hayashida, G. J. Partida, and A. T. Ishida : "Dissociation of retinal ganglion cells without enzymes", Journal of Neuroscience Methods, Vol.137, No.1, pp.25-35 (2004)

(22) Y. Hayashida, T. Motomura, and N. Murayama : "Vibrodissociation of rat retinal ganglion cells attached with inhibitory synaptic boutons", Investigative Ophthalmology \& Visual Science, Vol.47, E-Abstract 3763 (2006)

(23) R. Horn and A. Marty : "Muscarinic activation of ionic currents measured by a new whole-cell recording method", Journal of General Physiology, Vol.92, No.2, pp.145-159 (1988)

(24) E. E. Nattie, M. B. Bergin, J. Daley, and J. Melton : "CSF and brain ions, acid-base balance, and ventilation in acute hyponatremia", Journal of Applied Physiology, Vol.49, No.1, pp.95-101 (1980)

(25) C. M. Armstrong and W. F. Gilly : "Access resistance and space clamp problems associated with whole-cell patch clamping", Methods in Enzymology, Vol.207, pp.100-122.

(26) A. T. Ishida and M. H. Chen : "Cold inhibits neurite outgrowth from single retinal ganglion cells isolated from adult goldfish", Experimental Eye 
Research, Vol.52, No.2, pp.175-191 (1991)

(27) S. A. Lipton and D. L. Tauck : "Voltage-dependent conductances of solitary ganglion cells dissociated from the rat retina", Journal of Physiology, Vol.385, pp.361-391 (1987)

(28) B. A. Barres, B. E. Silverstein, D. P. Corey, and L. L. Chun : "Immunological, morphological, and electrophysiological variation among retinal ganglion cells purified by panning", Neuron, Vol.1, No.9, pp.791-803 (1988)

(29) T. Tabata and A. T. Ishida : "A zinc-dependent $\mathrm{Cl}^{-}$current in neuronal somata", Journal of Neuroscience, Vol.19, No.13, pp.5195-5204 (1999)

(30) C. F. Vaquero, A. Pignatelli, G. J. Partida, and A. T. Ishida : "A dopamineand protein kinase A-dependent mechanism for network adaptation in retinal ganglion cells", Journal of Neuroscience, Vol.21, No.21, pp.8624-8635 (2001)

(31) Y. Hayashida and A. T. Ishida : "Dopamine receptor activation can reduce voltage-gated $\mathrm{Na}^{+}$current $\mathrm{b}$ y modulating both entry into and recovery from inactivation", Journal of Neurophysiology, Vol.92, No.5, pp.3134-3141 (2004)

(32) J. Rae, K. Cooper, P. Gates, and M. Watsky : "Low access resistance perforated patch recordings using amphotericin B", Journal of Neuroscience Methods, Vol.37, No.1, pp.15-26 (1991)

(33) V. H. Perry : "The ganglion cell layer of the retina of the rat: a Golgi study", Proceedings of the Royal Society of London. Series B, Containing papers of a Biological character. Royal Society, Vol.204, No.1156, pp.363-375 (1979)

(34) E. Guenther, S. Schmid, R. Grantyn, and E. Zrenner : "In vitro identification of retinal ganglion cells in culture without the need of dye labeling", Journal of Neuroscience Methods, Vol.51, No.2, pp.177-181 (1994)

(35) A. T. Ishida and B. N. Cohen : "GABA-activated whole-cell currents in isolated retinal ganglion cells", Journal of Neurophysiology, Vol.60, No.2, pp.381-396 (1988)

(36) H. Gao, X. Qiao, F. Hefti, J. G. Hollyfield, and B. Knusel : "Elevated mRNA expression of brain-derived neurotrophic factor in retinal ganglion cell layer after optic nerve injury", Investigative Ophthalmology \& Visual Science, Vol.38, No.9, pp.1840-1847 (1997)

(37) A. T. Ishida : "Ion channel components of retinal ganglion cells", Progress in Retinal and Eye Research, Vol.15, No.1, pp.261-280(1995)

(38) K. R. Huxlin and A. K. Goodchild : "Retinal ganglion cells in the albino rat: revised morphological classification", Journal of Comparative Neurology, Vol.385, No.2, pp.309-323 (1997)

(39) B. J. O'Brien, T. Isayama, R. Richardson, and D. M. Berson : "Intrinsic physiological properties of cat retinal ganglion cells", Journal of Physiology, Vol.538, No.3, pp.787-802 (2002)
本 村 珠 美 (学生員) 2005 年熊本大学工学部電気システム 工学科卒業, 2007 年同大学院自然科学研究科電 気システム専攻博士前期課程修了, 現在同博士 後期課程在学中。神経生理学研究に従事。電子 情報通信学会会員。

林 田 祐 樹 （正員）1993 年九州工業大学情報工学部卒業,

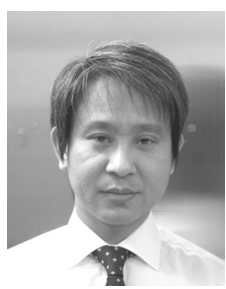
1998 年同大学院情報工学研究科博士後期課程 満了, 1999 年学振未来開拓学研推進事業プロジ エクトリサーチアソシエイト, 2001 年カリフォ ルニア大学デイビス校生物学部神経生物生理 行動学科ポストドクトラルフェロー, 2004 年熊 本大学工学部電気システム工学科助教授, 現在 同大学院自然科学研究科情報電気電子工学専 攻准教授。博士(情報工学)。神経科学/工学研究に従事。電子情報通 信学会 MBE 研究専門委員幹事, 日本計測自動制御学会, 日本電気 学会, 日本神経科学会, 米国神経科学学会, 米国視覚と眼科学研究 協会(ARVO) 各会員。

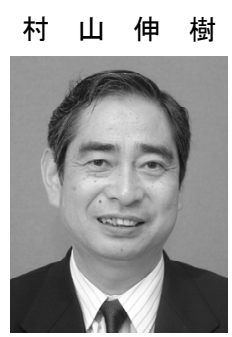

（正員） 1974 年熊本大学工学部電気工学科卒 業, 宮崎医科大学医学部生理学第一講座, 熊本 大学医学部生理学第二講座を経て, 1987 年同大 学工学部電気情報工学科助教授, 1995 年教授, 現在に至る。医学博士。感覚, 脳・神経系に関 する電気生理学的研究に従事。日本生理学会, 日本臨床神経生理学会, 日本生体磁気学会 各 評議員, 電子情報通信学会 MBE 研究会専門委員 長, 日本味と匂学会監査委員, 日本神経科学学会, 日本神経学会 各 会員。 